\title{
1 Air Quality Considerations for Stormwater Green Street Design
}

2 Kathryn M. Shaneyfelt ${ }^{\mathrm{a}^{*}}$, Andrew R. Anderson ${ }^{\mathrm{b}}$, Prashant Kumar ${ }^{\mathrm{c}}$, and William F. Hunt III ${ }^{\mathrm{a}}$ 3

aDepartment of Biological and Agricultural Engineering, North Carolina State University, Box 7625, Raleigh, NC 27695, United States

6

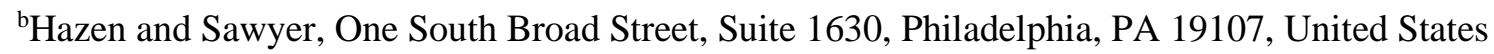

${ }^{\mathrm{c}}$ Global Centre for Clean Air Research (GCARE), Department of Civil and Environmental 10 Engineering, Faculty of Engineering and Physical Sciences, University of Surrey, Guildford GU2 11 7XH, United Kingdom

*Corresponding author, kmconroy@ncsu.edu

\section{Graphical abstract}

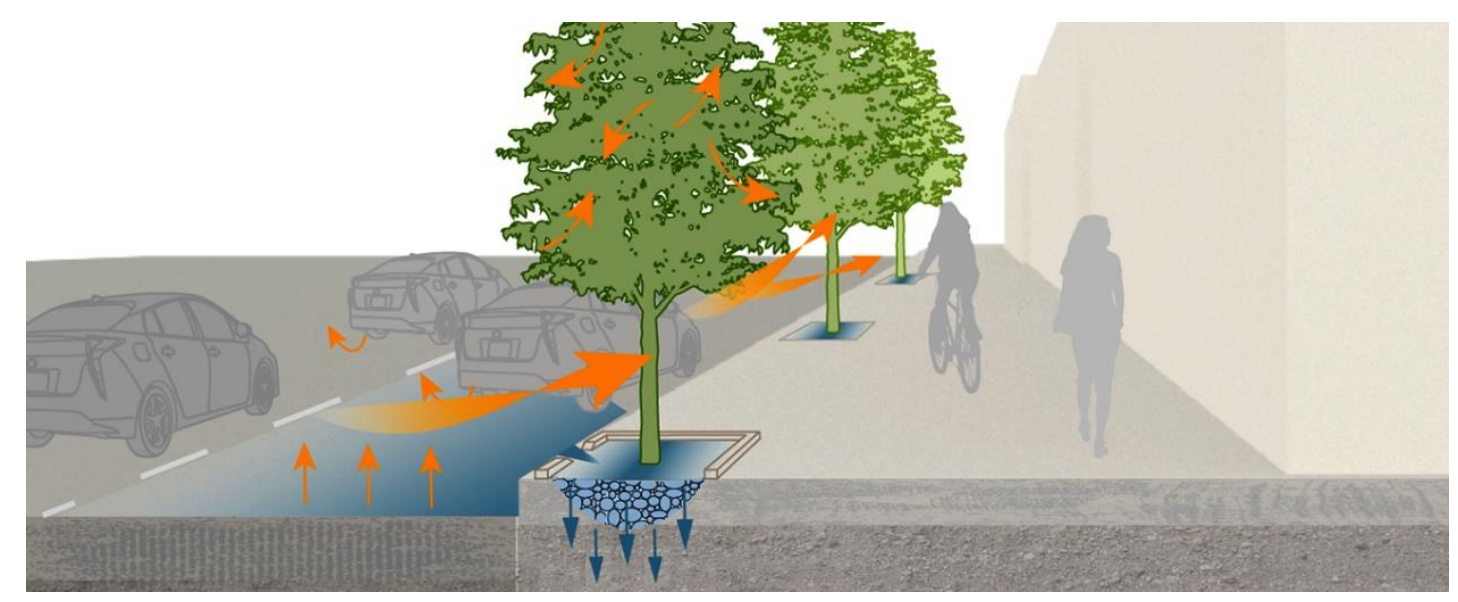

\section{Abstract}

Green streets are increasingly being used as a stormwater management strategy to mitigate stormwater runoff at its source while providing other environmental and societal benefits, including connecting pedestrians to the street. Simultaneously, human exposure to particulate matter from urban transportation is of major concern worldwide due to the proximity of pedestrians, drivers, and cyclists to the emission sources. Vegetation used for stormwater treatment can help designers limit the exposure of people to air pollutants. This goal can be achieved through the deliberate placement of green streets, along with strategic planting schemes that maximize pollutant dispersion. This 
review presents general design considerations for green streets that combine stormwater management and air quality goals. There is currently limited guidance on designing green streets for air quality considerations; this is the first review to offer suggestions and advice for the design of green stormwater streets in regards to their effects on air quality. Street characteristics including (1) the width to height ratio of the street to the buildings, (2) the type of trees and their location, and (3) any prevailing winds can have an impact on pollutant concentrations within the street and along sidewalks. Vegetation within stormwater control measures has the ability to reduce particulate matter concentrations; however, it must be carefully selected and placed within the green street to promote the dispersion of air flow.

Keywords: Green Streets; Stormwater; Air Quality; Street Trees; Particulate Matter

\section{Highlights}

- Green streets can be used for both stormwater and air quality management.

- Design considerations must be made to minimize human exposure to air pollutants.

- Urban vegetation can improve air quality with careful selection and placement.

\section{Introduction}

Urbanization is a major demographic trend in the 21 st century, with an estimated $54 \%$ of the world's population living in urban areas today (UN 2015). A key land use development activity associated with urbanization is construction of impervious surfaces such as roadways, driveways, buildings, and parking lots. Impervious cover leads to increased stormwater volumes, higher peak flows, and larger pollutant loads entering receiving water bodies (James 1965; Leopold 1968), with as little as 5\% impervious cover in a watershed being correlated with the start of stream degradation (Schueler et al. 2009). Concurrently, air pollution is a major public health problem worldwide (Kumar et al. 2015, 2016). In urban areas more than $80 \%$ of people are exposed to air pollutant levels that exceed limits set by the World Health Organization (WHO 2016). Outdoor air pollution was estimated to cause 3.7 million premature deaths worldwide, with mortality linked to exposure to particulate matter $\leq 10$ $\mu \mathrm{m}$ in diameter $\left(\mathrm{PM}_{10}\right)(\mathrm{WHO} 2014)$.

Transportation corridors constitute one of the largest categories of impervious land uses in urban areas, comprising $28 \%$ of all impervious area in an analysis of six urban and sub-urban watersheds in the United States (Tilley and Slonecker 2006), nearly equivalent to the $29 \%$ of area occupied by buildings. An analysis of 20 major cities in Europe, North America, and Oceania showed an average 
of $26 \%$ city core land allocated to streets, ranging from Moscow and Auckland (14 and 18\%, respectively) to Toronto and New York City (34 and 36\%, respectively) (UN Habitat 2013). Roadways dramatically impact hydrology and water quality because they typically directly connect impervious areas, resulting in the rapid conveyance of pollutants such as sediment, heavy metals, nutrients, bacteria, and oils and greases without opportunity for removal (US EPA 2007). Because (1) the right-of-way transportation corridor is often the jurisdiction of a city and (2) of its preponderance to discharge high volumes of stormwater per mm of rainfall vis-à-vis other land uses, many municipalities see the roadway as an opportunity to reduce stormwater volume. Moreover, motor traffic using these roadways is one of five major anthropogenic sources of air pollution (along with industry, power plants, trade, and domestic fuel) (Mayer 1999). Road traffic emissions of particulate matter have several sources including exhaust, brake wear, and tire wear emissions along with the resuspension of road dust from moving vehicles (Charron and Harrison 2005). The focus of this review is to link these two environmental and societal challenges - increased stormwater runoff and air pollution - in the guise of a transportation corridor known as a "green street," which will be defined later in this review.

\section{Traditional Roadway Design}

Historically, roadway design has focused almost exclusively on automobile transportation. The primary goals of roadway design in urban areas are motorist and pedestrian safety, levels of service, and flow capacity (vehicles per unit time per lane). Resultant design parameters of these goals include speed limits, horizontal and vertical curvature, parking incorporation, street width, and lane width (Lindeburg 2014). More hydraulically-efficient designs minimize the spatial and temporal extent of water spread, and therefore improve motorist safety.

\section{Complete Streets and Green Streets}

A broad design term used by urban planners is "complete streets". This encompasses the holistic planning of multi-modality transportation corridors, promoting safe, convenient, and comfortable travel for cyclists, pedestrians, and vehicles. "Green streets" are often defined to meet environmental, aesthetic, and quality of life goals under the larger umbrella of complete street design. To date, over 300 jurisdictions in the United States have adopted some form of Complete Streets policy (UN Habitat 2013). Green streets with respect to stormwater treatment are much newer, as they are developmentally linked with the increasing concern over water quality starting in the early 1990s in the United States. "Green streets" refer to transportation corridors in which low impact development 
(LID, Fletcher et al. 2015) is employed as a design principle by using a variety of green stormwater infrastructure (GSI) practices to treat direct transportation surface drainage in the right-of-way. In addition to structural control measures, green streets can also be characterized by imperviousreducing design measures such as narrower road sections. Of the seventeen North American jurisdictions with official green streets programs found by the authors, all but one included stormwater treatment as a primary goal in its definition of "green streets". While a green street may employ green amenities (plants and landscaping), the principle of "green" in the street design sense generally refers to preserving environmental quality. Many cities seek a holistic purpose for green street design, defining green streets as ecosystems that "are part of the natural landscape" (City of Austin 2015), increase safety and walkability, improve air quality and minimize the urban heat island effect (City of Philadelphia 2014), and provide attractive landscapes while enhancing neighborhood livability (City of Pamona 2014).

Green streets typically involve combinations of stormwater control measures (SCMs) and road design practices to reduce runoff. The most common SCMs used in the right-of-way include bioretention, bioswales, vegetation planter filtration/infiltration boxes, permeable pavement, and suspended pavement street tree systems (Figure 1). Bioretention cells are shallow, vegetated depressions containing engineered soil media, often with underdrains $0.6-1.2 \mathrm{~m}$ below the surface (Hunt et al. 2012). Bioretention / bio-infiltration has been studied for stormwater pollutant removal since the early 2000s, showing the ability to infiltrate the majority of small rainfall events (Brown and Hunt 2011; Davis et al. 2009; Asleson et al. 2009; Shuster et al. 2007) as well as remove many common urban pollutants (Davis et al. 2009). Permeable pavement infiltrates direct rainfall or runon from other impervious surfaces (Eisenberg et al. 2015), resulting in potentially significant volume reduction (Wardynski et al. 2013; Fassman and Blackbourn 2010) and pollutant sequestration (Bean et al. 2007; Brown et al. 2015). Suspended pavement street systems use un-compacted soil underneath sidewalks or streets that have one or more full-canopy trees that can access this soil that is fed with stormwater runoff. A suspended pavement street tree stormwater system with sub-grade soil storage in North Carolina, USA, showed mass load reductions for total phosphorus, total suspended solids, copper, lead and zinc of 91\%, 54\%, 88\%, and 77\%, respectively (Page et al. 2015a). The presence of full-canopy street trees alone can reduce stormwater volumes and pollutant loads through canopy interception (Lormand 1988; Xiao et al. 1998; Inkiläinen et al. 2013). Only components of green streets (rather than the entire green street) have been extensively monitored and published as peer-reviewed studies (Table 1). Individually, the SCMs show promise, reducing total volumes, pollutant concentrations and loads. SCMs are the practices designers can modify to not 
127 (such as air quality).

129
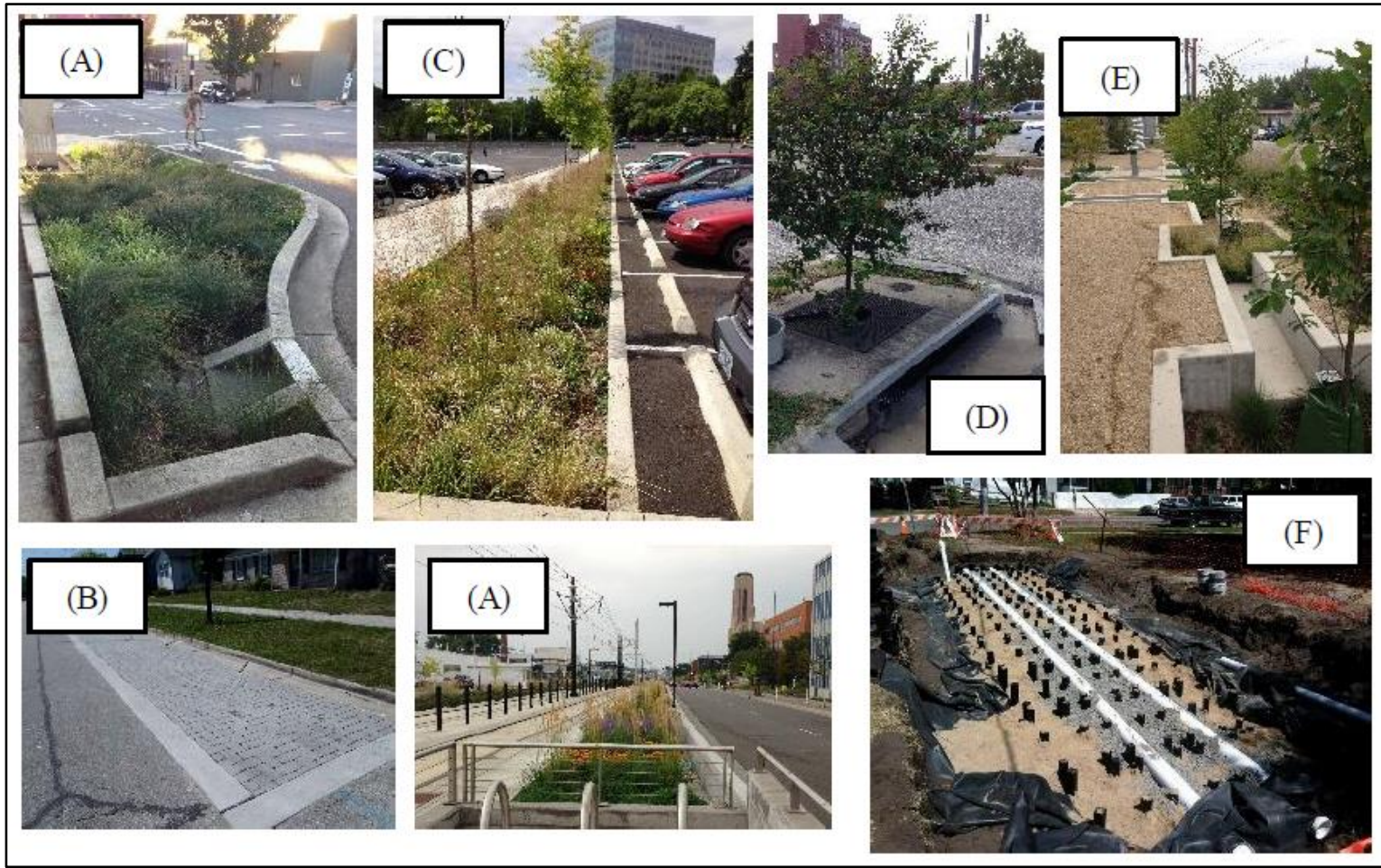

Figure 1. Common stormwater control measures used on green streets. (A) Bioretention, (B) biofiltration unit, $(\mathrm{E})$ tree planter infiltration boxes, $(\mathrm{F})$ suspended pavement street tree soil storage before final surfacing and tree planting.

Cost is often a barrier for green street implementation, affecting how and when to retrofit. Seattle, Washington's "SEA" street added traffic calming features to 0.40 lane-kilometers (treating 0.93 ha) of a residential access road, by adding right-of-way vegetation and permeable pavement, cost US\$ 1.14 million when adjusted for inflation in 2015 (Horner et al. 2002). This retrofit completely captured an estimated $93 \%$ of rainfall events relative to pre-construction (Horner et al. 2002). In contrast, a 0.54 lane-km (0.53 ha) retrofit on a residential road in Wilmington, NC, USA cost an estimated $\$ 85,000$ USD for two bioretention cells, two permeable pavement parking sections, and one tree filter box, resulting in a mean runoff depth decrease of 52\% (Page et al. 2015b). Other projects' costs have ranged from $\$ 314,000$ (in 2016 dollars) (Seattle, Washington, Horner 2004) to $\$ 15.8$ million (Atlanta, Georgia, Shamma 2015). Costs vary per many factors, including the type and quantity of SCM employed. The justification of the extra expenditure of green street retrofits can be 
bolstered by accounting for multiple streams of benefits, especially those outside of runoff and waterborne pollutant mitigation (Moore and Hunt 2012).

\section{Other Benefits of Green Streets}

As evident in the definition of green streets by major municipalities, benefits other than stormwater management are expected and planned for. Urban vegetation provides shade and evapotranspirational cooling, helping mitigate the urban heat island effect (Norton et al. 2015; Solecki et al. 2005). Napoli et al. (2016) found negative correlations between measured asphalt surface temperature in the shade of urban trees and the leaf area index of the trees themselves. Ward et al. (2008) found that properties in Seattle abutting four well-known green street projects sold for 3.5 to $5 \%$ more during the period after the adjacent streets were built, controlling for similar square footage, building quality, and lot size. Groundwater recharge increase has been observed with green infrastructure use (Girling and Kellett 2005; Council for Watershed Health 2010).

As practitioners begin to think holistically about meeting multi-phase goals of green streets other than traffic patterns and drainage design, more comprehensive data are needed on ancillary benefits that go into specific design decision. As green street goals specifically include attracting pedestrians and cyclists to the streetscape, the interaction between vehicular emissions and human exposure becomes evident. Therefore, it is in the interest of planners and engineers to consider the air quality impacts of putting vegetation in the right-of-way, as is the practice with green street implementation.

\section{Air Quality vis-à-vis Green Streets}

Persistent urbanization, a rising world population, and an increasing rate of car ownership (Dargay et al. 2007) leads to a growing number of people being exposed to air pollution (Baldauf et al. 2013). The 'green' part of green streets - trees and vegetation - could assist in improving air quality and reducing individual's exposure to unhealthy pollutants in the urban air (Nowak et al. 2006; Tiwary et al. 2009). Urban plants, including individual trees, herbaceous vegetation, and forests, have been shown to accumulate particulate matter from the atmosphere (Table 2, Nowak 1994; Freer-Smith et al. 1997; McDonald et al. 2007; Dzierżanowski et al. 2011). In addition to stormwater management goals, designers of green streets should attempt to minimize the exposure of people to harmful pollution by maximizing the dispersion of pollutants (Oke 1988).

Exposure to particulate matter in urban areas can increase the risk of numerous negative health effects, including cardiovascular and respiratory diseases and lung cancer (WHO 2016). Fine 
particulate matter, which refers to particles $\leq 2.5 \mu \mathrm{m}$ in diameter $\left(\mathrm{PM}_{2.5}\right)$, is especially harmful to humans because these particles can lodge deeply into the lungs upon inhalation, with some penetrating into the alveoli of the lungs (Samet et al. 2000; Heal et al. 2012; US EPA 2016). While cycling and walking are encouraged in cities around the world as a healthy and sustainable mode of transport, active commuters are receiving higher pollution doses than individuals using motorized transport (Colvile et al. 2001; Gulliver and Briggs 2007; Panis et al. 2010; Dirks et al. 2012).

Urban 'hot-spots' of poor air quality can include traffic intersections, busy roadsides, and street canyons (Goel and Kumar 2014). Higher levels of traffic emissions and restricted natural ventilation can lead to elevated pollutant concentrations at these hot-spots (Ahmad et al. 2005). Particulate matter concentrations in urban areas can be reduced by lowering their emission, increasing dispersion, and/or improving deposition rates (Pugh et al. 2012). Using strategically planned vegetated SCMs and street trees within green streets to filter, intercept, deposit, and absorb both the $\mathrm{PM}_{2.5}$ and $\mathrm{PM}_{10}$ will help improve the life expectancy of citizens in urban areas (Pope et al. 2009). When examining the particulates (quantity, morphology, and elemental analysis of particles) present on tree leaves, urban trees have been found to remove particulate matter from the atmosphere (FreerSmith et al. 1997; Beckett et al. 2000c). Additionally, researchers have determined that trees closer to busy roads capture more particulate matter than those farther from the road (Beckett et al. 2000b; Mori et al. 2015). Nowak et al. (2014) predicted that trees and forests in urban areas within the conterminous United States removed an estimated 27,000 tonnes of $\mathrm{PM}_{2.5}$ in 2010 with an associated removal value of $\$ 3.1$ billion in regards to human health. The ability of green streets to improve air quality is dependent on the vegetation present (species, age, porosity, number of plants, location), the climate (in-leaf season, precipitation amounts, wind speeds, relative humidity), the location of the SCMs relative to the emission source, and the characteristics of the street and pollution (Nowak et al. 2006; Buccolieri et al. 2009; Gromke and Ruck 2012).

205

\section{Vegetation and Particulate Matter Interactions}

207 Reducing the concentration of particulate matter in the atmosphere through interception, filtration, 208 deposition, and absorption is a valuable ecosystem service provided by urban vegetation (Nowak et 209 al. 2006; Yan et al. 2016). Vegetation types ranging from trees, shrubs, grasses, herbs, and climbers 210 have been shown to accumulate particulate matter and act as air pollutant sinks (Beckett 2000c; 211 Dzierżanowski et al. 2011; Weber et al. 2014). Brownian diffusion is the primary deposition 212 mechanism for ultrafine particles (those less than $0.1 \mu \mathrm{m}$ in diameter), while interception and 
213 impaction are the mechanisms that remove most fine (those $\leq 2.5 \mu \mathrm{m}$ in diameter) and coarse (those 214 between 2.5 and $10 \mu \mathrm{m}$ ) particulate matter (Hinds 1999; Lorenzini et al. 2006). Other characteristics 215 that can affect the deposition of particulate matter onto vegetation include the particle shape; the 216 location, shape, size, and porosity of vegetation present; and the temperature, relative humidity, and 217 wind speed (Buccolieri et al. 2009). Nowak et al. (2014) predicted that trees and forests in urban 218 areas within the conterminous United States removed approximately 27,000 tonnes of $\mathrm{PM}_{2.5}$ from 219 the atmosphere in 2010, while Jim and Chen (2008) estimated that urban trees within the city 220 removed $107 \mathrm{Mg}$ of total suspended particulates in one year in Guangzhuo, China.

222 While urban vegetation is often positively promoted as a method to improve air quality (McPherson 223 et al. 1994; Beckett et al. 1998; Nowak 2002), many studies have shown that adding vegetation, 224 especially trees, to hot-spots of air pollution (e.g., poorly ventilated areas along streets) can increase 225 pollutant concentrations by further restricting air flow and exchange (Gromke and Ruck 2007; 226 Buccolieri et al. 2009; Tiwary and Kumar 2014) (Figure 2). This highlights the need for smart urban 227 planning and a more thorough understanding of the best placement for various green infrastructure 228 systems.

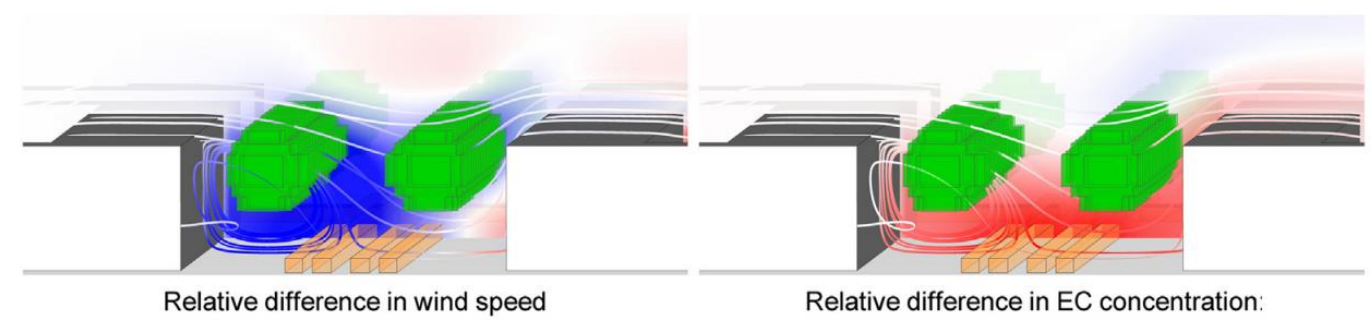

Relative difference in wind speed

Relative difference in EC concentration

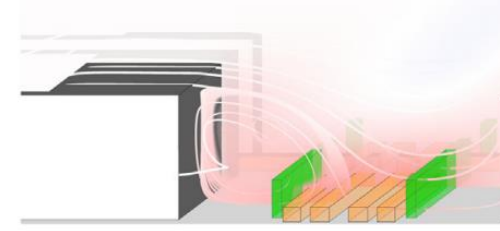

Relative difference in EC concentration:

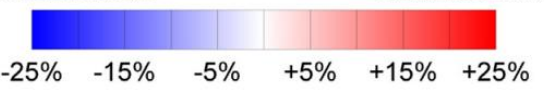

Figure 2. Example of vegetation's impact on air flow and pollutant concentrations in street canyons. Source: Vos et al. 2013.

\section{Street Trees}

Trees are considered the most efficient plant for particulate matter removal due to their large leaf surface area (Nowak 1994) and the turbulent mixing produced by the air passing through and over 
them (Beckett et al. 2000a). The removal of particulates from the atmosphere by plants occurs throughout the day and year-round through the interception of particulates by plant leaves and bark on trees (Nowak et al. 2006). However, certain seasons can have higher rates of particulate matter deposition than others, dependent upon vegetation types, pollutant emissions, and meteorological conditions (Nowak et al. 2006; Jim and Chen 2008; Schaubroeck et al. 2014). Also, particulate matter capture increases with higher wind speed (Beckett et al. 2000a; Nowak et al. 2013) and likely changes throughout the day (Nguyen et al. 2015). Additionally, trees placed near heavily trafficked roadways collect more particulate matter as compared to trees near less trafficked roadways (Beckett et al. 2000b; Mori et al. 2015). The size of the tree can also have an impact on its ability to trap particulate matter and other pollutants. Trees with diameters greater than $76 \mathrm{~cm}$ were predicted by Nowak (1994) to remove $1.4 \mathrm{~kg}$ of pollution per year, whereas, trees with diameters less than $8 \mathrm{~cm}$ were predicted to remove $0.02 \mathrm{~kg}$ of pollution per year. This increase in pollution removal rates for larger trees is attributed to their high leaf surface area compared to that of smaller trees. Hofman et al. (2014) looked at leaf density of tree crowns and particle deposition using Light Detecting and Ranging (LiDAR) data and demonstrated that an increase in leaf density decreased the deposition of particles. Nevertheless, the researchers asserted that the effect of leaf density on particle deposition was low compared to other tree characteristics including height and position (Hofman et al. 2014).

Although urban trees can provide extensive ecosystem services, the placement of street trees within street canyons can lead to localized increases in particulate matter concentrations (Gromke and Ruck 2007, 2009, 2012; Gromke et al. 2008; Buccolieri et al. 2009, 2011; Wania et al. 2012; Jin et al. 2014). An urban street canyon is a "relatively narrow street between buildings which line up continuously along both sides" (Nicholson 1975). Vardoulakis et al. (2003) suggested that an urban street having a width to height ratio of the street to the buildings equal to 1 may be called a regular street canyon. Jeanjean et al. (2015) performed computation fluid dynamic simulations of air pollutants using LiDAR data on buildings and trees in the city center of Leicester, UK. The researchers found that trees reduced air pollutants from traffic emissions by an average of $7 \%$ at breathing level for pedestrians due to an increase in turbulence; however, they also found that trees significantly increased the concentrations of traffic emission pollutants in deep street canyons. Street canyons with avenue-like tree plantings have reduced air flow velocities, inhibited air ventilation, and reduced dispersion and dilution (all of which lead to increased pollutant concentrations) compared to tree-free street canyons (Buccoleiri et al. 2009; Gromke et al. 2009; Gromke and Ruck 2012). 


\section{Roadside Vegetation Barriers}

271 Vegetation barriers can be placed along roads as an attempt to improve air quality, reduce noise 272 pollution, or for purely aesthetic reasons (Al-Dabbous and Kumar 2014). Green barriers are defined 273 by Vos et al. (2013) as "a solid (impermeable) screen covered with hedge-like vegetation at both 274 sides." Both hedges and green barriers were found to reduce the wind speed within the street canyon, 275 leading to higher pollutant concentrations in the driving lanes than in a street canyon with no 276 vegetation (Vos et al. 2013). The green barriers did shelter the pedestrians from increased pollutant 277 concentrations and improved the air quality on the sidewalk (Vos et al. 2013), while the hedges (due 278 to their porosity) did not. However, a roadside vegetative barrier in Surrey, UK, was found to reduce 279 the particle number concentration along the sidewalk during cross-road winds by $37 \%$ when 280 compared to a vegetation-free location These studies emphasize the need for further research on 281 vegetation barriers to determine optimal design specifications (i.e., placement, vegetation types, 282 barrier widths) for improving air quality along roadways, and also to investigate their (probably) modest stormwater mitigation benefits associated with interception.

\section{Vegetation Efficiencies}

286

287

288

289

290

291

292

293

294

Particulate matter removal depends on the species present (leaf type, angle, size, in-leaf season), plant placement, meteorological conditions (wind speed, precipitation, relative humidity), and the pollutant concentrations and emission sources (Beckett et al. 1998; Nowak et al. 2006; Litschke and Kuttler 2008; Buccolieri et al. 2009). Trees are the most efficient vegetation type at removing particulate matter due to the turbulence in air flow they cause as well as their large leaf surface areas (Beckett et al. 2000a)

For individual trees, both coniferous and broadleaf species have shown the ability to collect large amounts of particulate matter; however, coniferous trees are more effective than broadleaf trees due to their more complex shoot structure and fine needles (Beckett et al. 2000a; Beckett et al. 2000b; Freer-Smith et al. 2004; Sæbø et al. 2012; Räsänen et al. 2013). Other characteristics of trees that can enhance particulate matter accumulation include hairier leaves (Beckett et al. 2000a), rougher leaves (Beckett et al. 2000c; Tiwary et al. 2009), more leaf wax (Sæbø et al. 2012), and trees with greater structural complexity in their canopy, branches, and leaves (Beckett et al. 2000c; Freer-Smith et al. 2004). Becket et al. (2000c) demonstrated that larger trees collect more particulate matter than trees of the same species that are younger and smaller, but that the younger and smaller trees can still be effective in collecting particulate matter due to their higher foliage densities. The removal efficiency of ultrafine particles in a wind tunnel by pine and juniper was determined to be higher for 
smaller particle sizes, lower with increasing air velocity, and lower with decreased packing density (Lin and Khlystov 2012). Mori et al. (2015) found that coniferous trees located next to a highway in southwestern Norway intercepted $\mathrm{PM}_{10}$ and that the deposition efficiency was related to the tree species, needle age, and the distance from the highway. Capture efficiencies and particle accumulation for specific tree species can be found in Beckett et al. (2000a), Freer-Smith et al. (2004), and Blanusa et al. (2015).

Herbaceous plant species can also capture particulate matter (Dzierżanowski et al. 2011; Speak et al. 2012; Weber et al. 2014). Analysis of leaves harvested from roadside herbaceous vegetation in Berlin showed that species with the highest particulate matter accumulation rates were ones with hairy or rough leaves and that leaves $15 \mathrm{~cm}$ or higher from the ground collected more particulate matter (Weber et al. 2014). Herbs with smooth leaves and grasses were found to accumulate less particulate matter than other plants with hairy leaves (Weber et al. 2014).

\section{Discussion: General Design Considerations for Green Streets}

Green street implementation often involves adjusting roadway design parameters in concert with structural and landscape features that treat runoff. For example, road narrowing and removal of curb and gutter are two staples of the green streets (City of Seattle 2010). The choice of which SCMs is also key. Currently, the most common factors that influence the type of practice include: postconstruction road width and shape, vehicular loading (permeable pavement), capital cost, line of sight, soil infiltration capacity, above and below-ground utilities, adjacent private buy-in, social acceptance (gaged during initial stages of the project), maintenance capability of SCM owner, influence on integrity of pavement sub-base and surface material vis-à-vis ponded water, and the ability to meet other green street goals such as tree cover, aesthetics, etc.

However, green street design and SCM selection could additionally be based on air quality factors, as illustrated in the graphical abstract. Vegetated SCMs that have the ability to trap particulate matter and potentially improve air quality include: right-of-way bioswales, stormwater bump-outs, bioretention cells, suspended pavement systems with street trees, and flow-through filter boxes. These SCMs are often located close to road traffic emission sources (along roadways and in parking lots) and can have diverse combinations of plant species. The close proximity of the vegetation to the particulate matter emission sources maximizes the efficiency of interception and deposition; also, the smaller plants, shrubs, and grasses in these SCMs do not significantly hinder air flow within the street (Litschke and Kuttler 2008). 
339 The strategic placement and design of green infrastructure is necessary to enhance particulate matter

340 capture and to prevent the possibility of green infrastructure inadvertently worsening air quality.

341 Vegetated green infrastructure systems can be employed in urban areas to potentially reduce

342 pedestrian and cyclist exposure to particulate matter, especially from vehicle traffic emissions.

343 Although trees within street canyons may worsen localized air quality, one must remember that trees,

344 vegetation, and forests in urban areas can significantly reduce regional air pollution (Nowak et al.

345 2006; McDonald et al. 2007; Tiwary et al. 2009). Characteristics that can affect pollutant

346 concentrations in street canyons includes the width to height ratio $(\mathrm{W} / \mathrm{H})$ of the street to the buildings,

347 wind direction, and tree positioning and arrangement (Gromke and Ruck 2007; Buccolieri et al. 2009,

348 2011; Wania et al. 2012). This review offers suggestions and advice for the placement, design, and

349 planting scheme of stormwater green streets when considering their air quality impacts.

350

351 Considerations for the Placement of Green Streets

352 Carefully selecting the location of a future green street based on air quality considerations can

353 enhance the ecosystem services, in regards to trapping air pollutants, provided by the vegetated

354 SCMs. Green streets with trees would ideally be placed in non-street canyons and in areas without

355 high traffic. However, this is not always possible in urban areas because of space constraints and

356 other goal-driven needs for trees (e.g., stormwater management, urban cooling, aesthetics). Under

357 these constraints, only specific street canyons are feasible for green streets implementation. Factors

358 that affect the performance of a green street with respect to air quality include the W/H ratio of the

359 street canyon, any prevailing winds, and the climatic region in which the green street is built

360 (Buccolieri et al. 2009, 2011; Gromke and Ruck 2012; Setälä et al. 2013). Table 3 provides design

361 guidance for green streets within street canyons.

362

363 Buccolieri et al. (2009) found that the $\mathrm{W} / \mathrm{H}$ ratio of the street canyon and approaching wind velocity were the most critical factors in regards to pollutant concentration, compared to tree stand density and crown porosity. The researchers found that as $\mathrm{W} / \mathrm{H}$ increases, the effect of trees on pollutant concentration decreases no matter the tree morphology or arrangement (Buccolieri et al. 2009). For street canyons with trees, a $\mathrm{W} / \mathrm{H}=1$ can reduce flow by $62 \%$, while in a wider street $(\mathrm{W} / \mathrm{H}=2)$ the flow is reduced by 33\% (Buccolieri et al. 2009). Large increases in pollutant concentrations occurred within the street canyon (with trees) for all scenarios tested as compared to a tree-less street canyon 370 (Buccolieri et al. 2009). Jin et al. (2014) monitored PM $_{2.5}$ concentrations within street canyons (tree371 free and with trees) in Shanghai, China. In tree-free street canyons, $\mathrm{PM}_{2.5}$ concentrations decreased 
with increasing heights (Jin et al. 2014). However, in street canyons with trees, concentration reduction was less pronounced or even increased with increasing tree height (Jin et al. 2014). However, Vranckx et al. (2015) via modeling and wind tunnel validation showed the effect of trees within street canyons on air quality might be less pronounced than that predicted by other studies; annual average $\mathrm{PM}_{10}$ concentrations increased by only $1.4 \%$ after the addition of street trees.

Buccolieri et al. (2011) determined that wind flow perpendicular to the street axis in a street canyon with trees and a small $\mathrm{W} / \mathrm{H}$ ratio has the most impact on pollutant concentrations, whereas for a street canyon with trees and a larger $\mathrm{W} / \mathrm{H}$ ratio the impact is greatest when the wind flow is oblique $\left(45^{\circ}\right)$ to the street axis. Gromke and Ruck (2012) further found that an oblique wind direction had the greatest impact on pollutant concentrations within the modeled street canyon with trees for both W/H $=1$ and $\mathrm{W} / \mathrm{H}=2$. These studies highlight the need for designers and planners to consider both the street canyon ratio and prevailing winds when considering the placement of green streets. The research on street canyon ratios and prevailing winds suggests that the placement of the green streets is the most important factor when considering air quality (ahead of planting schemes and tree selection). Green streets with trees perhaps should not be placed in street canyon locations with strong perpendicular or oblique prevailing winds. Furthermore, until additional research has been performed placing green streets (with street trees) within street canyons with a $\mathrm{W} / \mathrm{H}$ ratio $\leq 2$ should probably be avoided, if air quality is at all a concern. Green streets built within these street canyons should employ SCMs that are designed without trees including permeable pavement, bioswales, stormwater bump-outs, and types of bioretention cells.

One way city planners and designers can prioritize green street placement when air pollution is a concern is to marry a green street canopy configuration with the local vehicle types and conditions seen on that particular street. Neighborhood roads with high bicycle traffic and only one lane of traffic may require addressing pollutant capture with tree canopies differently than a road trafficked by larger commercial delivery trucks and/or high volumes of personal vehicles.

Finally, the climatic region a green street is built in will likely influence its air quality performance. The role of vegetation in removing particulate matter from cities in subpolar climates may be less significant than in other climates due to shorter in-leaf seasons and the percentage of deciduous tree cover versus coniferous (Nowak et al. 2006; Setälä et al. 2013). Therefore, green streets built in subpolar climates may not need to be designed around enhancing air quality through trapping 
405

406

407

408

409

410

411

412

413

414

415

416

417

418

419

420

421

422

423

424

425

426

427

428

429

430

431

432

433

434

435

436

437

438

particulate matter; however, designers should be aware of green street characteristics that can diminish air quality.

\section{Planting Schemes and Management}

\section{Street Canyon Considerations}

Although trees can be effective at reducing particulate matter levels in urban areas, dense tree cover within street canyons should be avoided (Buccolieri et al. 2009, 2011; Wania et al. 2012; Vos et al. 2013; Abhijith et al., 2017). If there are trees within street canyons, Wania et al. (2012) recommends careful management of the crowns, including pruning, to promote air flow. Small tree crowns and trees with few leaves do not have much effect on pollutant concentrations; however, as tree crown diameter is increased the upward flow and dispersion of air become limited, leading to higher pollutant concentrations inside the street canyon (Gromke and Ruck 2007; Wania et al. 2012). It is recommended that there be adequate space between the tree crowns and nearby walls (Gromke and Ruck 2007) and the fewer trees that are planted leads to lower pollutant concentrations within the street canyon (Vos et al. 2013). Gromke and Ruck (2007) demonstrated that tree spacing also plays an important role in particulate matter concentrations and that close tree spacing within a street canyon negatively affects localized pollution concentrations. They estimated that increasing the spacing between trees from $15 \mathrm{~m}$ to $20 \mathrm{~m}$ decreased pollutant concentrations along one side of the street canyon by $26 \%$ with standing traffic and $9 \%$ for two-way traffic (Gromke and Ruck 2007).

Tree height is also an important factor, with Gromke and Ruck (2007) recommending that tree height shouldn't exceed the height of nearby buildings, due to changes in the level of entrained air in the street canyon. Wind tunnel and modeling experiments of trees within street canyons directed Buccolieri et al. (2009) to this recommendation: "A wider street canyon with two parallel aligned rows of trees [on each side of the street] is the preferable configuration which should be taken into account by urban planners rather than a narrow street canyon with only a single row of trees."

Including herbaceous vegetation in green street SCMs along with trees and shrubs can also help improve removal rates of particulate matter (Weber et al. 2014). All herbaceous roadside vegetation sampled in a study by Weber et al. (2014) was shown to assist in the trapping of particulate matter and the results demonstrated that different species captured different sizes and types of particulate matter - highlighting the benefit of using assorted species. For green streets within street canyons, designers may consider limiting the number of trees in bioretention cells and suspended pavement systems and focus on using SCMs with herbaceous vegetation (e.g., bioretention cells and bioswales). 
440 Finally, Vos et al. (2013) found that green barriers (impermeable screens with vegetation) may be 441 the only method of green infrastructure that can reliably reduce pedestrian exposure to particulate 442 matter within street canyons. The researchers found that the permeability of hedges allows air 443 pollutants to travel through them and into the sidewalk; however, Wania et al. (2012) speculated that 444 hedges may be able to capture particulate matter due to their proximity to vehicle emissions. 445 Although green barriers are not a SCM, they could be included in the green street design for aesthetics 446 and potential air quality improvements.

\section{Non-Street Canyon Considerations}

449 For green streets not located in street canyons or high-traffic areas, a planting scheme for a green 450 belt described by Freer-Smith et al. (2004) could be considered for trapping particulates. This 451 landscaping plan involves "low shrubs set in front of deciduous broadleaves and finally to position 452 evergreen conifers at the very back" (Freer-Smith et al. 2004). This is similar to a planting scheme 453 for a green belt described by Nguyen et al. (2015) who advocated for "one or two rows of shrubs, 454 followed by mixed evergreen (coniferous tree) and timber trees, and lastly with shrubs." Design 455 information provided on herbaceous vegetation and green barriers for street canyons also applies to 456 green streets not located in street canyons or highly-trafficked areas.

\section{Tree Selection}

459 Proper tree selection in urban areas can optimize particulate matter capture. Yang et al. (2015) looked 460 at the performance of the 100 most frequently occurring trees in 328 cities throughout the world in 461 removing particulate matter, as well as taking into account negative impacts the trees may have on 462 air quality and their suitability for urban areas. Of the ten most common tree species in urban areas, 463 only three were ranked as above average for their ability to trap particulates: London plane (Platanus 464 acerifolia), silver maple (Acer saccharinum), and honey locust (Gleditsia triacanthos). Other 465 particulate-trapping broadleaf species on that list were the Red maple (Acer rubrum), silver linden 466 (Tilia tomentosa), and American elm (Ulmus americana). While conifer trees are not frequently 467 planted in urban areas, Yang et al. (2015) saw their use as an opportunity to promote the planting of 468 certain conifers in cities. Also, evergreen conifers are more effective during the out-of-leaf season 469 than deciduous trees (Beckett et al. 2000b). However, conifers can be less tolerant to air pollution 470 from traffic and salt from road deicing (Dzierżanowski et al. 2011; Burkhardt and Pariyar 2014). 471 Therefore, Beckett et al. (2000b) concluded that deciduous broadleaf species may be better for urban 472 planting despite their relatively lower particulate matter capture rates. Tiwary et al. (2016) developed 
473 a performance index for green infrastructure vegetation selection based on seven factors, including

474 pollution flux potential. Small-to-medium size trees and evergreen shrubs were found to be more

475 desirable in urban street landscaping than larger trees (Tiwary et al. 2016) in regards to air quality.

476 This is at odds with current green infrastructure practices of planting large trees for their stormwater

477 benefits and creating SCMs that enhance tree growth (Smiley et al. 2006).

478

479 Trees in urban areas that should be avoided, especially along streets or by pavement, include (1) trees

480 without tolerance to air pollutants, heat, and drought (2) trees with highly allergenic pollen and (3)

481 invasive species (Yang et al. 2015). Street trees tend to have high stress levels and relatively high

482 mortality rates (Nowak et al. 2004). Pavement and soil compaction can limit tree root growth (Smiley

483 et al. 2006) and an increase in impervious cover reduces infiltration (Leopold 1973), decreasing the

484 amount of soil-water available. However, suspended pavement systems, which may include

485 permeable pavement, can be used to provide lightly compacted soil for tree growth. Suspended

486 pavement systems have been shown to improve tree growth, color, and root growth compared to

487 trees growing in compacted soils (Smiley et al. 2006). Suspended pavement systems also provide

488 stormwater management benefits including reduced peak runoff rates and improved water quality

489 (Page et al. 2015a). Suspended pavement design recommendations are made specifically for tree

490 health and based upon a volume of soil (e.g., Marritz 2013); however, they currently do not mandate

491 (or even lead to) a $20 \mathrm{~m}$ tree spacing.

492

493 Proper management (e.g., watering, fertilizing, and pruning) is recommended to reduce mortality 494 rates and improve the ecosystem services provided by urban trees (Nowak et al. 2004; Jim and Chen 495 2008). Because trees within SCMs receive water and nutrients from runoff they treat (Passeport and 496 Hunt 2009) less management is needed for those trees (with the exception of pruning).

497

498 Summary and Future Research Needs

499 Strategic urban planning incorporating innovative systems and policies is necessary to reduce the 500 human health and environmental impacts of urbanization. Many municipalities implement green 501 infrastructure within the right-of-way transportation corridor as a means to comply with regulations 502 while also improving urban livability. Vegetated green infrastructure systems have the ability to 503 reduce particulate matter levels in urban areas (Beckett et al. 1998; Nowak et al. 2006), thus 504 improving the quality of life for urban citizens and increasing life expectancies (Samet et al. 2000; 505 Pope et al. 2009). Stormwater green streets can be designed to take advantage of the air quality 506 ecosystem services provided by street trees and vegetated SCMs including: bioswales, stormwater 
507 bump-outs, bioretention cells, suspended pavement, and flow-through filter boxes. Care must be

508 taken when designing and implementing green streets in potential urban hot-spots of poor air quality

509 because street trees can limit the upward flow and dispersion of air and pollutants. These hot-spots

510 can include traffic intersections, busy roadsides, and street canyons (Goel and Kumar 2014). Factors

511 that affect the air quality within stormwater green streets include their placement, planting schemes,

512 and tree selection as detailed in the paper. Based upon the current research available, green street

513 placement (in regards to street canyon ratios and prevailing winds) appears to be the most important

514 factor of the three impacting air quality assuming the green street will have street trees. Therefore,

515 until further research is performed, perhaps limiting green streets containing street trees to a W/H

516 ratio $>2$ should be considered. Additionally, perhaps green streets with trees should not be placed in

517 street canyon locations with strong perpendicular or oblique prevailing winds. Dense tree cover

518 should be avoided in green street canyons; tree height, spacing, crown diameter, and species can

519 affect particulate matter concentrations (Buccolieri et al. 2009; Wania et al. 2012; Vos et al. 2013).

520 Tree species should be carefully selected by green street designers to enhance particulate matter

521 capture, with more research needed on the capture efficiencies of trees commonly found in urban

522 areas. These issues highlight that careful planning and design of green streets in urban areas is

523 needed.

524

525 Further research is needed to determine the performance, design, and best placement of various

526 vegetated green infrastructure systems in regards to reducing particulate matter concentrations. The

527 negative impacts that street trees can have on air quality also need to be more clearly defined so that

528 systems can be placed where they will not increase exposure of the green street users to harmful

529 pollutants. The authors have provided design guidance for green streets and their air quality

530 considerations based on the current research available; however, there is a relative dearth of data on

531 the subject, limiting the formulation of more specific guidelines. This paper aims to promote further

532 research on the nexus of the urban stormwater management and air quality. This includes the

533 development of a decision-making process based upon quantitative data regarding green street

534 placement, planting schemes, and tree selection based on air quality. Specific research needs are

535 highlighted:

536 - The movement and air quality impacts of ultrafine particles (<100 nm) and vegetation's ability

537 to act as a sink for ultrafine particles needs to be investigated.

538 - Tree selection in regards to PM trapping (to provide guidance on trees best suited for SCMs)

539 - The impact of temporarily trapped particulate matter on subsequent wash-off water quality

540 - Tree spacing (between each other, buildings, and the road) 
- PM exposure in street canyons in regards to trees, W/H ratio, and other SCMs with vegetation

542 - Is there a safe $\mathrm{W} / \mathrm{H}$ ratio for street tree addition?

543 - The creation of more specific green street design guidelines for considering air quality based $544 \quad$ upon street characteristics, vehicular and pedestrian traffic levels, and climate.

545 Overall, SCM and green street design (size, height, species type), placement, and function 546 (particulate matter capture and air movement, nearby and downwind) must be better understood.

547

\section{Acknowledgements}

549 The authors thank the University Global Partnership Network (UPGN) of the University of Surrey 550 and NC State, along with the City of Fayetteville, North Carolina, for funding this research. The 551 authors would also like to thank Sheida Moin for creating the graphical abstract. 
Tables/Figures

Table 1. Summary of Select Green Streets with Monitored or Modeled Stormwater Data Available in the United States.

\begin{tabular}{|c|c|c|c|c|c|c|}
\hline Source & Location & $\begin{array}{l}\text { Install } \\
\text { phase } \\
\text { (retrofit/ } \\
\text { new) }\end{array}$ & $\begin{array}{l}\text { Year } \\
\text { built }\end{array}$ & $\begin{array}{c}\text { Length or } \\
\text { area treated }\end{array}$ & Characteristics & Quantified Stormwater Benefits \\
\hline $\begin{array}{c}\text { Page et } \\
\text { al.(2015b) }\end{array}$ & $\begin{array}{l}\text { Wilmington, } \\
\mathrm{NC} \text {, USA }\end{array}$ & retrofit & 2012 & $\begin{array}{c}0.54 \text { lane-km } \\
0.53 \text { ha }\end{array}$ & $\begin{array}{l}\text { Two bioretention bump outs to pinch } \\
\text { traffic, two permeable pavement } \\
\text { parallel parking sections, one tree } \\
\text { filtration box at watershed outlet. }\end{array}$ & $\begin{array}{l}28 \% \text { decreased peak flow, } 52 \% \text { decrease in mean } \\
\text { runoff depth; Runoff coefficient decreased from } \\
0.38 \text { to } 0.18 ; \text { Reductions in particle-bound } \\
\text { pollutant loads; no change in dissolved pollutant } \\
\text { concentrations }\end{array}$ \\
\hline $\begin{array}{l}\text { Horner et } \\
\text { al. }(2002)\end{array}$ & $\begin{array}{l}\text { Seattle, WA, } \\
\text { USA }\end{array}$ & retrofit & 2001 & $\begin{array}{c}0.40 \text { lane-km } \\
0.93 \text { ha }\end{array}$ & $\begin{array}{l}\text { Reduced road width of residential road } \\
\text { from } 7.6 \text { to } 4.3 \mathrm{~m} \text {, converted } 18 \mathrm{~m} \text { of } \\
\text { pavement right of way to tree and shrub } \\
\text { detention swales }\end{array}$ & $\begin{array}{l}93.2 \% \text { of rainfall events detained completely } \\
(2001-2003 \text { study); outflow reduced from } 1.52 \text { to } \\
0.03 \mathrm{~m}^{3} \text { per mm of rainfall }\end{array}$ \\
\hline $\begin{array}{l}\text { Horner and } \\
\text { Chapman } \\
\text { (2007) }\end{array}$ & $\begin{array}{l}\text { NW } 110^{\text {th }} \\
\text { Street, } \\
\text { Seattle, WA, } \\
\text { USA }\end{array}$ & retrofit & $\begin{array}{l}2002- \\
2003\end{array}$ & 7.4 ha & $\begin{array}{l}12 \text { bioretention cells in a } 274 \text {-meter } \\
\text { cascade series along the road, separated } \\
\text { by concrete weirs in a step-pool } \\
\text { configuration. }\end{array}$ & $\begin{array}{l}79 \% \text { of rain events did not discharge; completely } \\
\text { retained } 7.6 \text { mm events and smaller; maximum } \\
\text { estimated volume reduction is } 74 \% \text { during study; } \\
85-90 \% \text { total suspended solids reduction }\end{array}$ \\
\hline $\begin{array}{l}\text { D.C. DOT } \\
(2010)\end{array}$ & $\begin{array}{l}\text { Washington } \\
\text { D.C., USA }\end{array}$ & retrofit & 2012 & $\begin{array}{c}2.4 \text { lane-km } \\
0.86 \text { ha }\end{array}$ & $\begin{array}{l}2 \text { bioretention cells in the right-of-way, } \\
1 \text { bio-swale, } 12 \text { stormwater planters, } \\
\text { and permeable concrete sidewalk. }\end{array}$ & $\begin{array}{l}\text { SWMM pre-construction model estimates } 12 \% \\
\text { total volume reduction, fully captures } 25.4 \mathrm{~mm} \\
\text { event and 1-year, } 24 \text {-hour recurrence event }\end{array}$ \\
\hline
\end{tabular}


Table 2. Summary of Studies Addressing Urban Tree Particulate Capture.

\begin{tabular}{|c|c|c|c|}
\hline Location & Scope & Type of PM & PM Removal per year \\
\hline Chicago, USA ${ }^{\mathrm{a}}$ & Urban trees & $\mathrm{PM}_{10}$ & $212 \mathrm{t}$ \\
\hline Conterminous USA ${ }^{\mathrm{b}}$ & Urban trees & $\mathrm{PM}_{10}$ & $214,900 \mathrm{t}$ \\
\hline 50 cities in conterminous USA $^{b}$ & Urban trees & $\mathrm{PM}_{10}$ & $\begin{array}{l}3,570 \mathrm{t} \text { in Jacksonville, FL (highest) } \\
\text { to } 7 \mathrm{t} \text { in Bridgeport, CT (lowest) }\end{array}$ \\
\hline Guangzhou, China ${ }^{\mathrm{c}}$ & Urban trees & $\mathrm{TSP}^{\mathrm{g}}$ & $107 \mathrm{Mg}$ \\
\hline Midtown Toronto, Canada ${ }^{\mathrm{d}}$ & Urban trees and shrubs & $\mathrm{PM}_{10}$ & $8.3 \mathrm{Mg}$ \\
\hline 10 cities in conterminous $\mathrm{USA}^{\mathrm{e}}$ & Urban trees & $\mathrm{PM}_{2.5}$ & $\begin{array}{c}64.5 \mathrm{t} \text { in Atlanta, GA (highest) to } 4.7 \\
\mathrm{t} \text { in Syracuse, NY (lowest) }\end{array}$ \\
\hline Conterminous $\mathrm{USA}^{\mathrm{f}}$ & Urban trees & $\mathrm{PM}_{2.5}$ & $27,000 \mathrm{t}$ \\
\hline
\end{tabular}

$561 \quad \overline{{ }^{a}}$ Nowak, 1994, ${ }^{\mathrm{b}}$ Nowak et al. 2006, ${ }^{\mathrm{c}} \mathrm{Jim}$ and Chen 2008, ${ }^{\mathrm{d}}$ Currie and Bass 2008, ${ }^{\mathrm{e}}$ Nowak et al. 2013, ${ }^{\mathrm{f}}$ Nowak et al. 2014, ${ }^{\mathrm{g}}$ Total suspended particles 


\begin{tabular}{|c|c|c|c|}
\hline Element & Recommendation & Citation & Relation to SCM Design \& Maintenance \\
\hline Street W/H Ratio & $\begin{array}{l}\text { If } \mathrm{W} / \mathrm{H} \text { ratio } \leq 2 \text {, avoid adding trees (until } \\
\text { additional research performed). }\end{array}$ & $\begin{array}{l}\text { Buccolieri et al. 2009; } \\
\text { Jin et al. } 2014\end{array}$ & $\begin{array}{l}\text { Tree inclusion within bioretention, tree trenches, and } \\
\text { suspended pavement systems should be limited. }\end{array}$ \\
\hline Tree Selection & $\begin{array}{l}\text { Fewer trees are better. Dense tree cover should be } \\
\text { avoided. }\end{array}$ & $\begin{array}{l}\text { Buccolieri et al. 2009; } \\
\quad \text { Vos et al. } 2013\end{array}$ & $\begin{array}{l}\text { Tree inclusion within bioretention, tree trenches, and } \\
\text { suspended pavement systems should be limited. }\end{array}$ \\
\hline Tree Spacing & $\begin{array}{l}\text { Avoid close spacing between individual trees and } \\
\text { between trees and nearby buildings. }\end{array}$ & Gromke and Ruck 2007 & $\begin{array}{l}\text { Select smaller trees and/or be attentive to tree pruning. } \\
\text { Placement of suspended pavement systems may be } \\
\text { spaced out beyond that normally recommended. }\end{array}$ \\
\hline Tree Height & $\begin{array}{l}\text { Tree height should not exceed the height of nearby } \\
\text { buildings. }\end{array}$ & $\begin{array}{l}\text { Gromke and Ruck } \\
\text { 2007; Bassuk et al. } \\
2003\end{array}$ & $\begin{array}{l}\text { Select smaller trees and/or be attentive to tree pruning. } \\
\text { Example trees for North America that may be sufficien } \\
\text { include: Eastern Redbud (Cercis Canadensis), Winte } \\
\text { King Hawthorne (Crataegus viridis), Honey Locus } \\
\text { (Gleditsia triacanthos) }\end{array}$ \\
\hline Tree Crown Diameter & Avoid trees with large tree crown diameter. & $\begin{array}{l}\text { Gromke and Ruck } \\
\text { 2007; Wania et al. } 2012\end{array}$ & $\begin{array}{l}\text { Plant trees with small crowns and/or be attentive to tree } \\
\text { pruning. }\end{array}$ \\
\hline Other Vegetation & $\begin{array}{l}\text { Include a mix of herbaceous plants, grasses, and } \\
\text { shrubs within SCMs. Green barriers may be } \\
\text { effective at reducing pedestrian exposure. }\end{array}$ & $\begin{array}{l}\text { Nguyen et al. 2015; } \\
\text { Vos et al. 2013; Weber } \\
\quad \text { et al. } 2014\end{array}$ & $\begin{array}{l}\text { Include variety of herbaceous vegetation in bioretention } \\
\text { cells and bioswales to promote PM removal. Rows of } \\
\text { shrubs may be helpful. }\end{array}$ \\
\hline Prevailing Winds & $\begin{array}{l}\text { Avoid placing green streets in locations with } \\
\text { oblique or perpendicular prevailing winds. }\end{array}$ & $\begin{array}{l}\text { Buccolieri et al. 2011; } \\
\text { Gromke and Ruck } 2012\end{array}$ & $\mathrm{n} / \mathrm{a}$ \\
\hline Climatic Region & $\begin{array}{l}\text { Focus on not worsening air quality, not on } \\
\text { improving it in subpolar climates. }\end{array}$ & $\begin{array}{l}\text { Nowak et al. 2006; } \\
\text { Setälä et al. } 2013\end{array}$ & $\begin{array}{l}\text { Green streets in subpolar climates may not need to be } \\
\text { designed around enhancing air quality because role of } \\
\text { vegetation less significant in PM removal. }\end{array}$ \\
\hline Green Barriers & $\begin{array}{l}\text { Include them in hot spots to shield pedestrians } \\
\text { from particulates. }\end{array}$ & Vos et al. 2013 & $\begin{array}{l}\text { Green barriers are not considered an SCM, but some } \\
\text { research on their (probably) modest stormwater pollutant } \\
\text { attenuation is needed. }\end{array}$ \\
\hline
\end{tabular}




\section{References}

Abhijith, KV., Kumar, P., Gallagher, J., McNabola, A., Baldauf, RW., Pilla, F., Broderick, B., Sabatino. S.D., Pulvirenti, B., 2017. Air pollution abatement performances of green infrastructure in open road and built-up street canyon environments - A Review. Atmospheric Environment 162, 71-86.

Ahmad, K., Khare, M., and Chaudhry, K.K. 2005. Wind tunnel simulation studies on dispersion at urban street canyons and intersections-a review. Journal of Wind Engineering and Industrial Aerodynamics, 93, 697-717.

Al-Dabbous, A.N. and Kumar, P. 2014. The influence of roadside vegetation barriers on airborne nanoparticles and pedestrians exposure under varying wind conditions. Atmospheric Environment, 90, 113-124.

Asleson, B.C., Nestingen, R.S., Gulliver, J.S., Hozalski, R.M., and Nieber, J.L. 2009. Performance assessment of rain gardens. Journal of the American Water Resources Association, 45(4), 1019-1031.

Baldauf, R., McPherson, G., Wheaton, L., Zhang, M., Cahill, T., Bailey, C., Hempill Fuller, C., Withycombe, E., and Titus, K. 2013. Integrating Vegetation and Green Infrastructure into Sustainable Transportation Planning. Transportation Research Board. TR News, 288, 14-18.

Bassuk, N., Curtis, D.F., Marranca, B.Z., and Neal, B. 2003. Recommended Urban Trees: Site Assessment and Tree Selection for Stress Tolerance. Urban Horticulture Institute, Department of Horticulture, Cornell University, Ithaca, New York, USA.

Bean, E.Z., Hunt, W.F., and Bidelspach, D.A. 2007. Evaluation of Four Permeable Pavement Sites in Eastern North Carolina for Runoff Reduction and Water Quality Impacts. Journal of Irrigation and Drainage Engineering, 133(6), 583-592.

Beckett, K.P., Freer-Smith, P.H., and Taylor, G. 1998. Urban woodlands: their role in reducing the effects of particulate pollution. Environmental Pollution, 99, 347-360.

Beckett, K.P., Freer- Smith, P.H., and Taylor, G. 2000a. Particulate pollution capture by urban trees: effect of species and windspeed. Global Change Biology, 6, 995-1003.

Beckett, K.P., Freer Smith, P.H., and Taylor, G. 2000b. Effective tree species for local air quality management. Journal of Arboriculture, 26, 12-19.

Beckett, K.P., Freer-Smith, P.H., and Taylor, G. 2000c. The capture of particulate pollution by trees at five contrasting urban sites. Arboricultural Journal, 24, 209-230.

Blanusa, T., Fantozzi, F., Monaci, F., and Bargagli, R. 2015. Leaf trapping and retention of particles by holm oak and other common tree species in Mediterranean urban environments.Urban Forestry \& Urban Greening, 14(4), 1095-1101.

Brown, R. and Hunt, W.F. 2011. Underdrain configuration to enhance bioretention exfiltration to reduce pollutant loads. Journal of Environmental Engineering, 137(2), 1082-1091. 
620

621

622

623

624

625

626

627

628

629

630

631

632

633

634

635

636

637

638

639

640

641

642

643

644

645

646

647

648

649

650

651

652

653

654

655

656

657

658

659

660

661

662

663

664

665

666

667

668

669

Brown, R., and Borst, M. 2015. Nutrient infiltrate concentrations from three permeable pavement types. Journal of Environmental Management, 164, 74-85.

Buccolieri, R., Gromke, C., Di Sabatino, S., and Ruck, B. 2009. Aerodynamic effects of trees on pollutant concentration in street canyons. Science of the Total Environment, 407, 52475256.

Buccolieri, R., Salim, S.M., Leo, L.S., Di Sabatino, S., Chan, A., Ielpo, P., de Gennaro, G., and Gromke, C. 2011. Analysis of local scale tree-atmosphere interaction on pollutant concentration in idealized street canyons and application to a real urban junction. Atmospheric Environment, 45, 1702-1713.

Burkhardt, J. and Pariyar, S. 2014. Particulate pollutants are capable to 'degrade' epicuticular waxes and to decrease the drought tolerance of Scots pine (Pinus sylvestris L.). Environmental Pollution, 184, 659-667.

Charron, A. and Harrison, R.M. 2005. Fine (PM2.5) and Coarse (PM2.5-10) Particulate Matter on a Heavily Trafficked London Highway: Sources and Processes. Environmental Science \& Technology, 39, 7768-7776.

City of Austin, Texas. 2015. Green Streets: An Introduction. Accessed via: https://austintexas.gov/sites/default/files/files/Transportation/Complete_Streets/GreenStree tsWeb092115.pdf. Accessed: 22-Feb 2016.

City of Pamona, California. 2014. City of Pamona Green Streets Policy. Accessed via: http://ci.pomona.ca.us/mm/pubwrks/pdf/Pomona_Green_Streets_Policy_Final.pdf. Accessed 22-Feb 2016.

City of Philadelphia, Pennsylvania. 2014. City of Philadelphia Green Streets Design Manual. Philadelphia Water Department. Accessed via: http://www.phillywatersheds.org/what_were_doing/gsdm. Accessed: 23-Feb 2016.

Matsuno, H. and Chiu, S. 2010. SEA Street. City of Seattle, Seattle Public Utilities. Access via: http://nacto.org/docs/usdg/stormwater_management_challenge_matsuno.pdf. Accessed: Feb-23 2016.

Colvile, R.N., Hutchinson, E.J., Mindell, J.S., and Warren, R.F. 2001. The transport sector as a source of air pollution. Atmospheric Environment, 35, 1537-1565.

Dargay, J., Gately, D., and Sommer, M. 2007. Vehicle Ownership and Income Growth, Worldwide: 1960-2030. The Energy Journal, 28, 143-170.

Davis, A., Hunt, W., Traver, R., and Clar, M. 2009. Bioretention technology: Overview of current practice and future needs. Journal of Environmental Engineering, 135(3), 109-117.

Dirks, K.N., Sharma, P., Salmond, J.A., and Costello, S.B. 2012. Personal Exposure to Air Pollution for Various Modes of Transport in Auckland, New Zealand. The Open Atmospheric Science Journal, 6, 84-92.

D.C. DOT. 2014. The District of Columbia's Multimodal Long-Range Transportation Plan: 
Sustainability and Livability Element. District Department of Transportation, Policy, Planning \& Sustainability Administration. Accessed via: http://www.wemovedc.org/resources/Final/Part\%202_Plan_Elements/Sustainability_and_ Livability.pdf. Accessed: Feb-24 2016.

Dzierżanowski, K., Popek, R., Gawrońska, H., Sæbø, A., and Gawroński, S.W. 2011. Deposition of particulate matter of different size fractions on leaf surfaces and in waxes of urban forest species. International Journal of Phytoremediation, 13, 1037-1046.

Eisenberg, B., Lindow, K.C., and Smith, D.R., eds. 2015. Permeable Pavements. American Society of Civil Engineers.

Fassman, E.A. and Blackbourn, S. 2010. Urban Runoff Mitigation by a Permeable Pavement System over Impermeable Soils. Journal of Hydrologic Engineering, 15(6), 475-485.

Fletcher et al. 2015. SUDS, LID, BMPs, WSUD and more - The evolution and application of terminology surrounding urban drainage. Urban Water Journal 12(7), 525-542.

Freer-Smith, P.H., Holloway, S., and Goodman, A. 1997. The uptake of particulates by an urban woodland: site description and particulate composition. Environmental Pollution, 95, 2735 .

Freer-Smith, P.H., El-Khatib, A.A., and Taylor, G. 2004. Capture of particulate pollution by trees: a comparison of species typical of semi-arid areas (Ficus nitida and Eucalyptus globulus) with European and North American species. Water, Air, and Soil Pollution, 155, 173-187.

Girling, C. and Kellett, R. 2005. Skinny streets and green neighborhoods: Design for environment and community. Washington, DC: Island Press.

Goel, A. and Kumar, P. 2014. A review of fundamental drivers governing the emissions, dispersion and exposure to vehicle-emitted nanoparticles at signalised traffic intersections. Atmospheric Environment, 97, 316-331.

Gromke, C. and Ruck, B. 2007. Influence of trees on the dispersion of pollutants in an urban street canyon-experimental investigation of the flow and concentration field. Atmospheric Environment, 41, 3287-3302.

Gromke, C., Buccolieri, R., Di Sabatino, S., and Ruck, B. 2008. Dispersion study in a street canyon with tree planting by means of wind tunnel and numerical investigations-evaluation of CFD data with experimental data. Atmospheric Environment, 42, 8640-8650.

Gromke, C. and Ruck, B. 2009. On the impact of trees on dispersion processes of traffic emissions in street canyons. Boundary-Layer Meteorology, 131, 19-34.

Gromke, C. and Ruck, B. 2012. Pollutant concentrations in street canyons of different aspect ratio with avenues of trees for various wind directions. Boundary-Layer Meteorology, 144, 4164 .

Gulliver, J. and Briggs, D.J. 2007. Journey-time exposure to particulate air pollution. Atmospheric Environment, 41, 7195-7207. 
Heal, M.R., Kumar, P., and Harrison, R.M. 2012. Particles, air quality, policy and health. Chemical Society Reviews, 41, 6606-6630.

Hinds, W.C., 1999. Aerosol Technology: Properties, Behavior, and Measurement of Airborne Particles, second ed. Wiley, New York.

Hofman, J., Bartholomeus, H., Calders, K., Van Wittenberghe, S., Wuyts, K., and Samson, R. 2014. On the relation between tree crown morphology and particulate matter deposition on urban tree leaves: A ground-based LiDAR approach. Atmospheric Environment, 99, 130139.

Horner, R.R., Lim, H., and Burges, S.J. 2002. Hydrologic monitoring of the Seattle ultra-urban stormwater management projects. Water Resources Series Technical Report No. 170. Department of Civil and Environmental Engineering, University of Washington, Seattle, Washington, USA.

Horner, R.R., Lim, H., and Burges, S.J. 2004. Hydrologic monitoring of the Seattle ultra-urban stormwater management projects: summary of the 2000-2003 water years. Water Resources Technical Report No. 181. Department of Civil and Environmental Engineering, University of Washington, Seattle, Washington, USA.

Horner, R.R. and Chapman, C. 2007. NW $110^{\text {th }}$ Street natural drainage system performance monitoring. Prepared for Seattle Public Utilities. Department of Civil and Environmental Engineering, University of Washington, Seattle, Washington, USA.

Hunt, W.F., Davis, A.P., and Traver, R.G. 2012. Meeting Hydrologic and Water Quality Goals through Targeted Bioretention Design. Journal of Environmental Engineering, 138(6), 698 -707 .

Inkiläinen, E.N., McHale, M.R., Blank, G.B., James, A.L., and Nikinmaa, E. 2013. The role of residential urban forest in regulating throughfall: a case study in Raleigh, North Carolina, USA. Landscape and Urban Planning, 119, 91-103.

James, L.D. 1965. Using a digital computer to estimate the effects of urban development on flood peaks. Water Resources Research, 1(2), 223-234.

Jeanjean, A.P., Hinchliffe, G., McMullan, W.A., Monks, P.S., and Leigh, R.J. 2015. A CFD study on the effectiveness of trees to disperse road traffic emissions at a city scale. Atmospheric Environment, 120, 1-14.

Jim, C.Y. and Chen, W.Y. 2008. Assessing the ecosystem service of air pollutant removal by urban trees in Guangzhou (China). Journal of Environmental Management, 88, 665-676.

Jin, S., Guo, J., Wheeler, S., Kan, L., and Che, S. 2014. Evaluation of impacts of trees on PM 2.5 dispersion in urban streets. Atmospheric Environment, 99, 277-287.

Kumar, P., Khare, M., Harrison, R.M., Bloss, W.J., Lewis, A., Coe, H., and Morawska, L. 2015. New Directions: Air pollution challenges for developing megacities like Delhi. Atmospheric Environment, 122, 657-661. 
Kumar, P., Andrade, M.F., Ynoue, R.Y., Fornaro, A., de Freitas, E.D., Martins, Martins, J.L.D., Albuquerque, T., Zhang, Y., and Morawska, L. 2016. New Directions: From biofuels to wood stoves: the modern and ancient air quality challenges in the megacity of São Paulo. Atmospheric Environment, 140, 364-369.

Leopold, L.B. 1968. Hydrology for urban land planning - A guidebook on the hydrologic effects of urban land use. Circular 554, U.S. Geological Survey.

Leopold, L.B. 1973. River channel change with time: an example address as Retiring President of The Geological Society of America, Minneapolis, Minnesota, November 1972. Geological Society of America Bulletin, 84, 1845-1860.

Lin, M.Y. and Khlystov, A. 2012. Investigation of ultrafine particle deposition to vegetation branches in a wind tunnel. Aerosol Science and Technology, 46(4), 465-472.

Lindeburg, M.R. 2014. Civil Engineering Reference Manual for the P.E. Exam (14 ${ }^{\text {th }}$ ed.). Professional Publications, Inc., Belmont, CA. ISBN: 978-1-59126-453-8.

Litschke, T. and Kuttler, W. 2008. On the reduction of urban particle concentration by vegetation-a review. Meteorologische Zeitschrift, 17, 229-240.

Lorenzini, G., Grassi, C., Nali, C., Petiti, A., Loppi, S., and Tognotti, L. 2006. Leaves of Pittosporum tobira as indicators of airborne trace element and PM 10 distribution in central Italy. Atmospheric Environment, 40(22), 4025-4036.

Lormand, J.R. 1988. The effects of urban vegetation on stormwater runoff in an arid environment. Master's Thesis. School of Renewable Natural Resources, University of Arizona, Tucson, AZ, USA.

Marritz, L. 2013. Our Recommended Soil Volume for Urban Trees. DeepRoot - Green Infrastructure for your Community. Accessed via: http://www.deeproot.com/blog/blogentries/our-recommended-soil-volume-for-urban-trees. Accessed: 22-March 2017.

Mayer, H. 1999. Air pollution in cities. Atmospheric Environment, 33, 4029-4037.

McDonald, A.G., Bealey, W.J., Fowler, D., Dragosits, U., Skiba, U., Smith, R.I., Donovan, R.G., Brett, H.E., Hewitt, C.N., and Nemitz, E. 2007. Quantifying the effect of urban tree planting on concentrations and depositions of PM 10 in two UK conurbations. Atmospheric Environment, 41, 8455-8467.

McPherson, G.E., Nowak, D.J., and Rowntree, R.A. 1994. Chicago's urban forest ecosystem: results of the Chicago Urban Forest Climate Project. United States Department of Agriculture - Forest Service.

Moore, T.L. and Hunt, W.F. 2012. Ecosystem service provision by stormwater wetlands and ponds-A means for evaluation?. Water Research, 46(20), 6811-6823.

Mori, J., Hanslin, H.M., Burchi, G., and Sæbø, A. 2015. Particulate matter and element accumulation on coniferous trees at different distances from a highway. Urban Forestry \& Urban Greening, 14(1), 170-177. 
Napoli, M., Massetti, L., Brandani, G., Petralli, M., and Orlandini, S. 2016. Modeling tree shade effect on urban ground surface temperature. Journal of Environmental Quality, 45(1), 146156.

Nguyen, T., Yu, X., Zhang, Z., Liu, M., and Liu, X. 2015. Relationship between types of urban forest and PM 2.5 capture at three growth stages of leaves. Journal of Environmental Sciences, 27, 33-41.

Nicholson, S.E. 1975. A pollution model for street-level air. Atmospheric Environment, 9(1), 1931.

Norton, B.A., Coutts, A.M., Livesley, S.J., Harris, R.J., Hunter, A.M., and Williams, N.S.G. 2015. Planning for cooler cities: A framework to prioritise green infrastructure to mitigate high temperatures in urban landscapes. Landscape and Urban Planning, 134, 127-138.

Nowak, D.J. 1994. Air pollution removal by Chicago's urban forest. Chicago's urban forest ecosystem: Results of the Chicago urban forest climate project, USDA Forest Service, 63 81.

Nowak, D.J. 2002. The Effects of Urban Trees on Air Quality. USDA Forest Service. Northern Research Station, Syracuse, New York.

Nowak, D.J., Kuroda, M., and Crane, D.E. 2004. Tree mortality rates and tree population projections in Baltimore, Maryland, USA. Urban Forestry \& Urban Greening, 2(3), 139147.

Nowak, D.J., Crane, D.E., and Stevens, J.C. 2006. Air pollution removal by urban trees and shrubs in the United States. Urban Forestry \& Urban Greening, 4(3), 115-123.

Nowak, D.J., Hirabayashi, S., Bodine, A., and Hoehn, R. 2013. Modeled PM 2.5 removal by trees in ten US cities and associated health effects. Environmental Pollution, 178, 395-402.

Nowak, D.J., Hirabayashi, S., Bodine, A., and Greenfield, E. 2014. Tree and forest effects on air quality and human health in the United States. Environmental Pollution, 193, 119-129.

Oke, T.R. 1988. Street design and urban canopy layer climate. Energy and Buildings, 11(1), 103113.

Page, J.L., Winston, R.J., and Hunt, W.F. 2015a. Soils beneath suspended pavements: An opportunity for stormwater control and treatment. Ecological Engineering, 82, 40-48.

Page, J.L., Winston R.J., Mayes D.B., Perrin C., Hunt W.F. 2015b. Retrofitting with innovative stormwater control measures: Hydrologic mitigation of impervious cover in the municipal right-of-way. Journal of Hydrology, 527, 923-932.

Panis, L.I., De Geus, B., Vandenbulcke, G., Willems, H., Degraeuwe, B., Bleux, N., Mishra, V., Thomas, I., and Meeusen, R. 2010. Exposure to particulate matter in traffic: a comparison of cyclists and car passengers. Atmospheric Environment, 44 (19), 2263-2270.

Passeport, E. and Hunt, W.F. 2009. Asphalt Parking Lot Runoff Nutrient Characterization for Eight Sites in North Carolina, USA. Journal of Hydrologic Engineering, 14(4), 352-361. 
873

874

875

876

877

878

879

880

881

882

883

884

885

886

887

888

889

890

891

892

893

894

895

896

897

898

899

900

901

902

903

904

905

906

907

908

909

910

911

912

913

914

915

916

917

918

919

920

921

Pope, C.A., Ezzati, M., and Dockery, D.W. 2009. Fine-particulate air pollution and life expectancy in the United States. New England Journal of Medicine, 360, 376-386.

Pugh, T.A., MacKenzie, A.R., Whyatt, J.D., and Hewitt, C.N. 2012. Effectiveness of green infrastructure for improvement of air quality in urban street canyons. Environmental Science \& Technology, 46(14), 7692-7699.

Räsänen, J.V., Holopainen, T., Joutsensaari, J., Ndam, C., Pasanen, P., Rinnan, Å., and Kivimäenpää, M. 2013. Effects of species-specific leaf characteristics and reduced water availability on fine particle capture efficiency of trees. Environmental Pollution, 183, 6470.

Sæbø, A., Popek, R., Nawrot, B., Hanslin, H.M., Gawronska, H., and Gawronski, S.W. 2012. Plant species differences in particulate matter accumulation on leaf surfaces. Science of the Total Environment, 427, 347- 354.

Samet, J.M., Dominici, F., Curriero, F.C., Coursac, I., and Zeger, S.L. 2000. Fine particulate air pollution and mortality in 20 US cities, 1987-1994. New England Journal of Medicine, 343, 1742-1749.

Schaubroeck, T., Deckmyn, G., Neirynck, J., Staelens, J., Adriaenssens, S., Dewulf, J., Muys, B. and Verheyen, K. 2014. Multilayered modeling of particulate matter removal by a growing forest over time, from plant surface deposition to washoff via rainfall. Environmental Science \& Technology, 48(18), 10785-10794.

Schueler, T.R., Fraley-McNeal L., and Cappiella, K. 2009. Is impervious cover still important? Review of recent research. Journal of Hydrologic Engineering, 14(4), 309-315

Shamma, T. November 2015. Atlanta is Home to Largest Permeable Pavers Project in US. WABE - Atlanta's NP Station. Accessed via: http://news.wabe.org/post/atlanta-home-largestpermeable-pavers-project-us?nopop=1. Accessed: 18-April 2017.

Shuster,W.D., Gehring, R., and Gerken, J. 2007. Prospects for enhanced groundwater recharge via infiltration of urban storm water runoff: A case study. Journal of Soil and Water Conservation, 62(3), 129-137.

Setälä, H., Viippola, V., Rantalainen, A.L., Pennanen, A., and Yli-Pelkonen, V. 2013. Does urban vegetation mitigate air pollution in northern conditions?. Environmental Pollution, 183, 104-112.

Smiley, E.T., Calfee, L., Fraedrich, B.R., and Smiley, E.J. 2006. Comparison of structural and noncompacted soils for trees surrounded by pavement. Arboriculture and Urban Forestry, 32(4), 164-169.

Solecki, W.D., C. Rosenzweig, L. Parshall, G. Pope, M. Clark, J. Cox, and M. Wiencke. 2005. Mitigation of the heat island effect in urban New Jersey. Environmental Hazards, 6(1), 3949. 
Speak, A.F., Rothwell, J.J., Lindley, S.J., and Smith, C.L. 2012. Urban particulate pollution reduction by four species of green roof vegetation in a UK city. Atmospheric Environment, 61, 283-293.

Tilley, J.S. and Slonecker, E.T. 2006. Quantifying the components of impervious surfaces. Prepared for the U.S. Department of Transportation, Federal Highway Administration in collaboration with the U.S. EPA. No. 2007-1008.

Tiwary, A., Sinnett, D., Peachy, C., Chalabi, Z., Vardoulakis, S., Fletcher, T., Leonardi, G., Grundy, C., Azapagic, A., and Hutchings, T.R. 2009. An integrated tool to assess the role of new planting in PM10 capture and the human health benefits: a case study in London. Environmental Pollution, 157(10), 2645-2653.

Tiwary, A. and Kumar, P. 2014. Impact evaluation of green-grey infrastructure interaction on built-space integrity: an emerging perspective to urban ecosystem service. Science of the Total Environment, 487, 350-360.

Tiwary, A., Williams, I.D., Heidrich, O., Namdeo, A., Bandaru, V., and Calfapietra, C. 2016. Development of multi-functional streetscape green infrastructure using a performance index approach. Environmental Pollution, 208, 209-220.

United Nations Habitat (UN Habitat). 2013. Streets as Public Spaces and Drivers of Urban Prosperity. United Nations Human Settlements Programme, Nairobi, Kenya.

United Nations (UN). 2015. World Urbanization Prospects: The 2014 Revision. Department of Economic and Social Affairs, Population Division, United Nations, New York, New York.

U.S. EPA. 2007. National water quality inventory: Report to Congress-2002 reporting cycle. Rep. No. EPA 841-R-07-001, United States Environmental Protection Agency, Office of Water, Washington, D.C., U.S.A.

U.S. EPA. 2016. Particulate Matter. Accessed via: https://www3.epa.gov/pm/. Accessed: 27-May 2016.

Vos, P.E., Maiheu, B., Vankerkom, J., and Janssen, S. 2013. Improving local air quality in cities: to tree or not to tree?. Environmental Pollution, 183, 113-122.

Vranckx, S., Vos, P., Maiheu, B., and Janssen, S. 2015. Impact of trees on pollutant dispersion in street canyons: A numerical study of the annual average effects in Antwerp, Belgium. Science of the Total Environment, 532, 474-483.

Wania, A., Bruse, M., Blond, N., and Weber, C. 2012. Analysing the influence of different street vegetation on traffic-induced particle dispersion using microscale simulations. Journal of Environmental Management, 94, 91-101.

Ward, B., MacMullan, E., and Reich, S. 2008. The Effect of Low Impact Development on Property Values. Proceedings of the Water Environment Federation, Sustainability, 318 - 323.

Council for Watershed Health. 2010. Water augmentation study: Research, strategy, and implementation report. Los Angeles and San Gabriel Rivers Watershed Council. Accessed 
via: http://www.usbr.gov/lc/socal/reports/LASGwtraugmentation/report.pdf. Accessed: 22-March 2017.

Weber, F., Kowarik, I., and Säumel, I. 2014. Herbaceous plants as filters: Immobilization of particulates along urban street corridors. Environmental Pollution, 186, 234-240.

World Health Organization (WHO). 2014. Ambient (outdoor) air quality and health: fact sheet. Accessed via: http://www.who.int/mediacentre/factsheets/fs313/en/. Accessed: 27-May 2016.

World Health Organization (WHO). 2016. WHO Global Urban Ambient Air Pollution Database (update 2016). Accessed via:

http://www.who.int/phe/health_topics/outdoorair/databases/cities/en/. Accessed 27-May 2016.

Xiao, Q., McPherson, E.G., Simpson, J.R., and Ustin, S.L. 1998. Rainfall interception by Sacramento's urban forest. Journal of Arboriculture, 24, 235-244.

Yan, J., Lin, L., Zhou, W., Ma, K., and Pickett, S.T. 2016. A novel approach for quantifying particulate matter distribution on leaf surface by combining SEM and object-based image analysis. Remote Sensing of Environment, 173, 156-161.

Yang, J., Chang, Y., and Yan, P. 2015. Ranking the suitability of common urban tree species for controlling PM 2.5 pollution. Atmospheric Pollution Research, 6(2), 267-277. 